Article

\title{
Thermal Simulation of Phase Change Material for Cooling of a Lithium-Ion Battery Pack
}

\author{
Seyed Saeed Madani *[D, Erik Schaltz $(\mathbb{D})$ and Søren Knudsen Kær (i) \\ Department of Energy Technology, Aalborg University, DK-9220 Aalborg, Denmark; esc@et.aau.dk (E.S.); \\ Skk@et.aau.dk (S.K.K.) \\ * Correspondence: ssm@et.aau.dk
}

Received: 11 September 2020; Accepted: 10 December 2020; Published: 15 December 2020

\begin{abstract}
A new heat transfer enhancement approach was proposed for the cooling system of lithium-ion batteries. A three-dimensional numerical simulation of the passive thermal management system for a battery pack was accomplished by employing ANSYS Fluent (Canonsburg, PA, USA). Phase change material was used for the thermal management of lithium-ion battery modules and as the heat transmission source to decrease battery temperature in fast charging and discharge conditions. Constant current charge and discharge were applied to lithium-ion battery modules. In the experimental part of the research, an isothermal battery calorimeter was used to determine the heat dissipation of lithium-ion batteries. Thermal performance was simulated for the presence of phase change material composites. Simulation outcomes demonstrate that phase change material cooling considerably decreases the lithium-ion battery temperature increase during fast charging and discharging conditions use. The greatest temperature at the end of $9 \mathrm{C}, 7 \mathrm{C}, 5 \mathrm{C}$, and $3 \mathrm{C}$ charges and discharges were approximately $49.7,44.6,38.4$, and $33.1^{\circ} \mathrm{C}$, respectively, demonstrating satisfactory performance in lithium-ion battery thermal homogeneity of the passive thermal management system.
\end{abstract}

Keywords: thermal management; lithium titanate oxide batteries; phase change material

\section{Introduction}

Lithium-ion battery cells are everywhere; in cameras, cell phones, laptops, and in lots of other electronic appliances. Currently, they have been selected for more demanding utilizations such as electric and hybrid vehicles. As battery applications and sizes rise, novel battery management and control approaches are required to enhance the battery pack's reliability, safety, lifetime, and performance, especially in the application of electric and hybrid vehicles in which the battery cell is exposed to an abrupt culmination of both discharge and charge power in comparison with approximately steady charge and discharge current in the application of mobile electronic appliances.

Due to their big power and energy densities, lithium-ion batteries are a considerably essential element of electric vehicles. Their application has increased noticeably in the last few years [1-7]. One of the important issues of employing lithium-ion batteries in electric and hybrid vehicles is appropriate thermal management. Proper thermal management is essential with the intention of controlling degradation at a satisfactory rate. In addition, it is important to decrease the risk of thermal runaway.

It is usually appropriately comprehended that enhancing the working temperature of a lithium-ion battery tends to raise the degradation rate. Notwithstanding, there is insufficient comprehension regarding the advantageous technique to control the lithium-ion battery cells in a battery pack thermally. Besides, the influences of temperature gradients among battery cells in a battery pack are not well-understood [8-12]. 
Considerable cooling procedures have been suggested and investigated. Chen and Evans explicated a two-dimensional model to scrutinize the influence of different cell constituents, stack dimensions, and cooling states on the functioning of Li-polymer electrolyte batteries under dissimilar discharge paces. Appertaining to the temperature thumbnail sketches attained, they presented worthwhile sagaciousness like how to sustain functioning temperature by contriving appropriate cell stacks and selecting suitable conservational schemes from a heat relocate standpoint [13].

Al-Hallaj et al. investigated the thermal performance of business-related cylinder-shaped and heterogeneous Li-ion cells employing electrochemical-calorimetric techniques. They calculated the cell heat production the whole time the cell discharges and energy utilization throughout the cell charging period with consequential dependency on the condition of charge at the end of discharge because of intensification polarity [14].

Maleki and Shamsuri appraised the thermal functioning of a notebook Li-ion battery pack under different functioning states mathematically. They discovered that the battery temperature escalation throughout the charge is preponderated by the power wastage from the control electronics and pending discharge by the heat wastage from Li-ion cells [15].

Pesaran et al. improved a thermal pattern to forecast temperature dispersions in battery cells, components, and packs. The research utilized elementary heat transmission rules and finite element investigations to generate temperature repartition representations of an electric vehicle battery pack. In addition, electromagnetic photography and liquid crystal thermography were utilized to gain photographs turning the spotlight on the thermal repartitions. The methodology for this research was to unravel the $2 \mathrm{D}$ transitory heat conduction mathematical statement for a collection of components utilizing finite element investigation [16].

Onda et al. reconnoitered the thermal demeanor of lithium-ion batteries from end to end fast charge and discharge cycles. In this study in order to gauge the heat starting place factors of the cell at a fixed temperature, the cell was charged and discharged while enveloped in the slim electrical isolating lamina and submerged in a water thermostat. The cell was charged and discharged two times at the graded situation to obliterate any preceding charge and discharge memoir [17].

Choi and Kang [18] elaborated on a thermal model to construct the flow systematization and characterize the suitable cooling method for an air-cooled hybrid electric vehicle. Wang et al. [19,20], Yang et al. [21] and $\mathrm{Xu}$ et al. [22] developed the optimization of battery alignment and air movement channel, correspondingly, to attain improved efficiency from air cooling.

Zhao et al. [23] studied the parametric effect on a cylinder-shaped battery unit employing air cooling. The metal froth was subjoined to ameliorate air-cooling efficiency by Mohammadian et al. [24]. Sadrameli et al. [25] investigated thermal management of a lithium-ion battery pack at big temperature ambiance by employing a compound of aluminum wire mesh plates and phase change materials. Karimi et al. [26] experimentally investigated on a lithium-ion battery thermal management system by employing composite phase change materials and achieved the result that metal matrix phase change material composites decline the greatest temperature difference among the lithium-ion battery surface and composite phase change material to seventy percent. Zaho et al. expressed dissimilar thermal management system procedures, from those procedures, inferring that phase change materials are considerably efficacious technology for lithium-ion batteries thermal management systems [27].

Seemingly, most investigations about phase change material for thermal management of lithium-ion batteries described in the literature have been concentrated on the lithium-ion battery with a cylindrical shape and phase change material in quadric form. Phase change material cooling in circular shape employed for rectangular lithium-ion batteries has not been satisfactorily studied. In addition, previous investigations did not use an isothermal battery calorimeter for the determination of lithium-ion batteries' heat generation and thermal management by using phase change materials. This investigation demonstrates considerable scientific advancement and improvement in the comprehension of thermal management in lithium-ion battery cells. 


\section{Methodology}

Battery thermal quantifications in this experimentation were carried out by touching-base thermocouples in the calorimeter hollow with temperature control. The isothermal battery calorimeter is a robust instrument fabricated for the correct determination of heat flux produced by batteries while being charged or discharged under the experiential situation. Control parts inside the calorimeter are shown in Figure 1.

The isothermal battery calorimeter unit contains one cabinet $(650 \mathrm{lbs} .300 \mathrm{~kg})$, which is empty, and the thermal fluid appends in the vicinity of $250 \mathrm{lbs} . / 114 \mathrm{~kg}$ of supplementary weight and computer links to the instrument cabinet through two USB 2.0 cable. The experimental setup used in this investigation is illustrated in Figure 2. As illustrated in the figure, the experimental setup consists of different parts, such as the Maccor automated test system, isothermal battery calorimeter, data acquisition system, and battery cell.

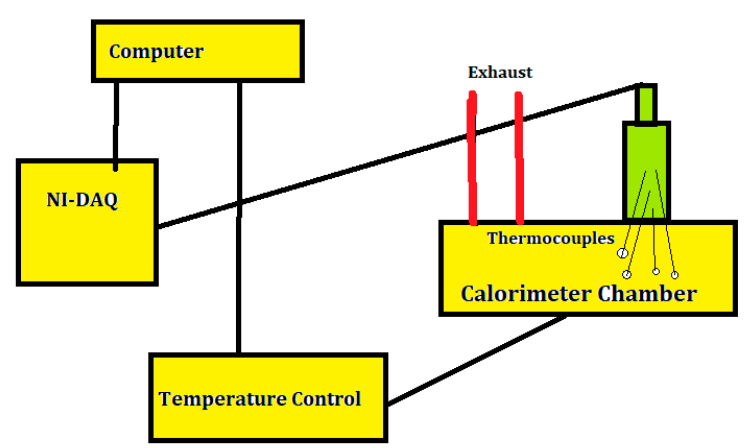

Figure 1. Control parts inside the calorimeter.

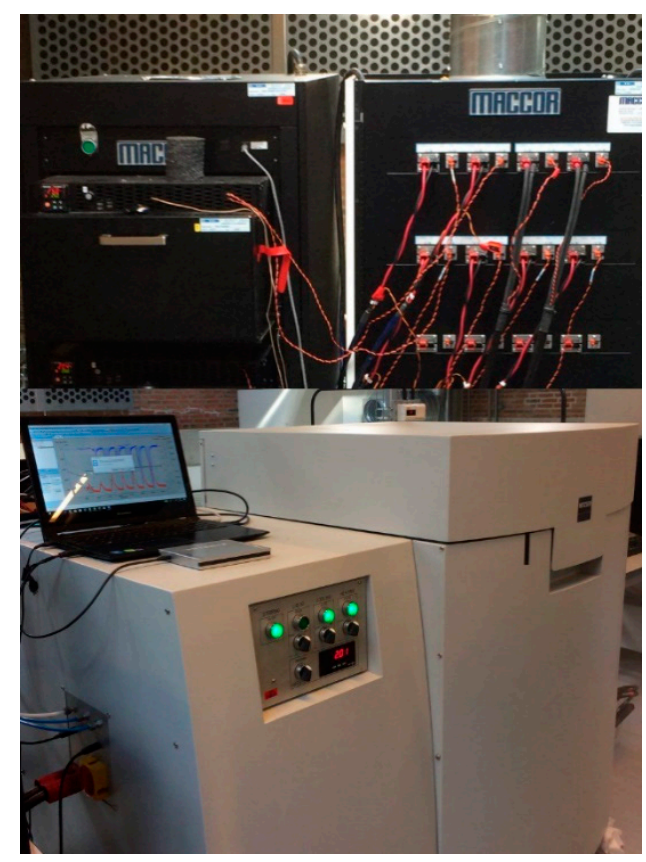

Figure 2. Experimental setup.

The experiential prearrangement is controlled by the graphical user interface of the LabVIEW front panel interface. The data obtained from the isothermal battery calorimeter allows engineers to distinguish and characterize materials and arrangements appropriate for developed battery thermal management systems. The isothermal battery calorimeter comprises a large volume analysis chamber, 
submerged in an isothermal bath. Temperatures on the exteriority of the battery cell were quantified by means of touching base thermocouples in the experimental part of the research.

\section{Controlling Equations}

It was assumed that the heat was evenly generated throughout the lithium-ion battery. In addition, phase change material was considered homogenous. According to the assumptions, the governing energy equation could be described with the following equation [28]:

$$
\rho \frac{\partial E}{\partial t}=k\left(\frac{\partial^{2} E}{\partial x^{2}}+\frac{\partial^{2} E}{\partial y^{2}}+\frac{\partial^{2} E}{\partial z^{2}}\right)+Q
$$

The initial condition could be expressed as,

$$
\begin{aligned}
& T(x, y, z)=T_{0} \\
& t=0
\end{aligned}
$$

The second type Neumann boundary condition could be described as follows,

$$
-K_{P C M} \frac{\partial T_{P C M}}{\partial_{n}}=0
$$

where:

E-Enthalpy [J].

$Q-$ Heat generation rate [W].

T-Temperature [K].

$T_{0}$-Initial temperature [K].

$x, y, z$-Cartesian coordinates [m].

$t$-Time [s].

$k$-Thermal conductivity [ $\mathrm{W} \mathrm{m}^{-1} \mathrm{~K}^{-1}$ ].

$n-$ Normal direction.

PCM-Phase change material

Figure 3 illustrates the modeling method for thermal analysis. Different thermal fields, including improved heat transfer material, heat generation resource, and latent heat storage material are required to be calculated for the thermal simulation. Consequently, a three dimensional, implicit, segregated, and unsteady solver was designated. In addition, the energy model and melting/solidification were used. Thermal terms of interfaces among phase change material and battery were supposed to be coupled. An absolute criterion for energy and other equations were considered $10^{-6}$. 


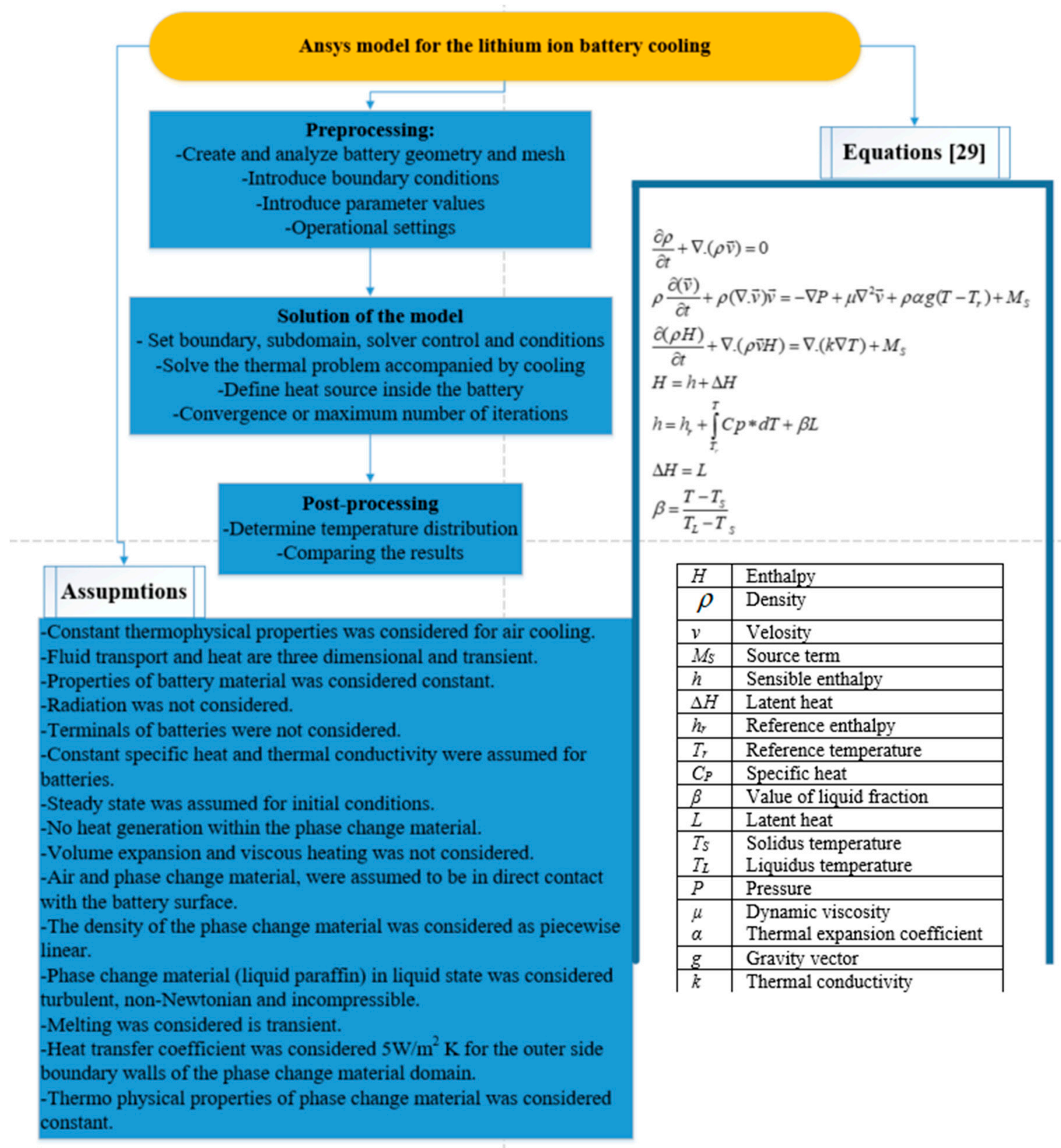

Figure 3. The modeling method for thermal analysis. Equations were adapted from [29].

\section{Result and Discussion}

Thermal management of the lithium-ion battery is a considerably complicated problem. The solution for thermal management will be dissimilar for different pack topologies, battery cells, and different applications. A new method for simulating and modeling the thermal behavior of the battery was developed. A significant temperature heterogeneousness appears on the surface of the lithium-ion batteries, particularly at significant current rates. This occurrence might be expressed by an immense amount of heat loss owing to a more significant temperature gradient. Moreover, the amount of surface temperature of the battery cell, estimated by the thermal model, was compared with the experimental data. Correspondingly, the construct of a suitable thermal management system, particularly during big current rates; discharging and charging could play an essential role in stopping significant temperature growth of the battery cell [30,31]. 
The principal purpose of this research is to evaluate if and how the battery thermal management system can be designed to assure battery pack safety and increase the lifetime of batteries. Temperature is one of the most important features affecting both the performance and lifespan of a battery pack. Battery thermal management is indispensable in attaining functioning and lengthening the life of batteries in electric vehicles. Consequently, the focus of this research was to create a more efficient, simpler, and less costly thermal management system for batteries by using computational fluid dynamics supported by extensive laboratory experiments. The principal purposes can be shortened along these lines:

-Maintain battery cells in the favorite temperature scope.

-Minimize cell-to-cell temperature alterations.

-Barricade the battery from functioning in higher or lower allowable bounds.

-Maximize the energy utilization of battery cells and pack.

Numerous calorimetric experiments were done to understand the thermal behavior of the battery cell under dissimilar conditions. From the result of previous studies, it is feasible to infer that the amount of heat loss is in relation to the correspondent current rate. Particularly this achievement would contribute to advance battery thermal modeling. Furthermore, previous studies' consequences could be employed for battery cell thermal modeling and the construct of appropriate thermal management systems. Various experimental research was accomplished on the thermal and electrical performances of the lithium-ion battery. Experimental investigations were restricted to surface temperatures integrated with heat dissipation thermal or analytical modeling to achieve battery temperatures and determine the battery cell's total heat loss.

Heat loss evolution during different current rates was taken from [31]. These results were considered as an input for the thermal simulation of the batteries. A creative technique was used for the thermal management of lithium-ion batteries via an isothermal battery calorimeter. Heat loss measurements were used as input for this thermal analysis. Furthermore, a dynamic heat source was considered for battery thermal analysis. The battery surface temperatures were used for the validation of the thermal model [32].

The computational fluid dynamics software, Fluent, by ANSYS, was used to generate the fluid movement computer simulation for this research. The software uses the finite-volume technique to mathematically untangle the physical determining mathematical statements for the fluid. Fluent presents an encyclopedic scope of contrivances to generate physics-based configurations for a wide-ranging of utilizations. The energy mathematical statement can be resolved to model combined heat transmission moot points containing all mechanisms of heat transfer such as conduction, convection, and radiation. Many kinds of fluid stream predicaments can be modeled containing incompressible, compressible, laminar, and turbulent flows. User-defined functions authorize the utilization of novel models beyond the bounds of the abundant constructed in Fluent simulations. An illustration of the lithium-ion battery pack design for the battery thermal management system with phase change material is demonstrated in Figure 4. The solidification and melting model of ANSYS Fluent software was employed to model the melting of the thermal management system. The problem was solved by employing the finite volume approach using ANSYS Fluent software. The meshed model is shown in Figure 5. A coupled method algorithm was used for pressure and velocity coupling. Green's gauss node was used for gradient discretization. The pressure was discretized by using a second-order scheme. The second-order upwind method was used to discretized momentum and energy. 

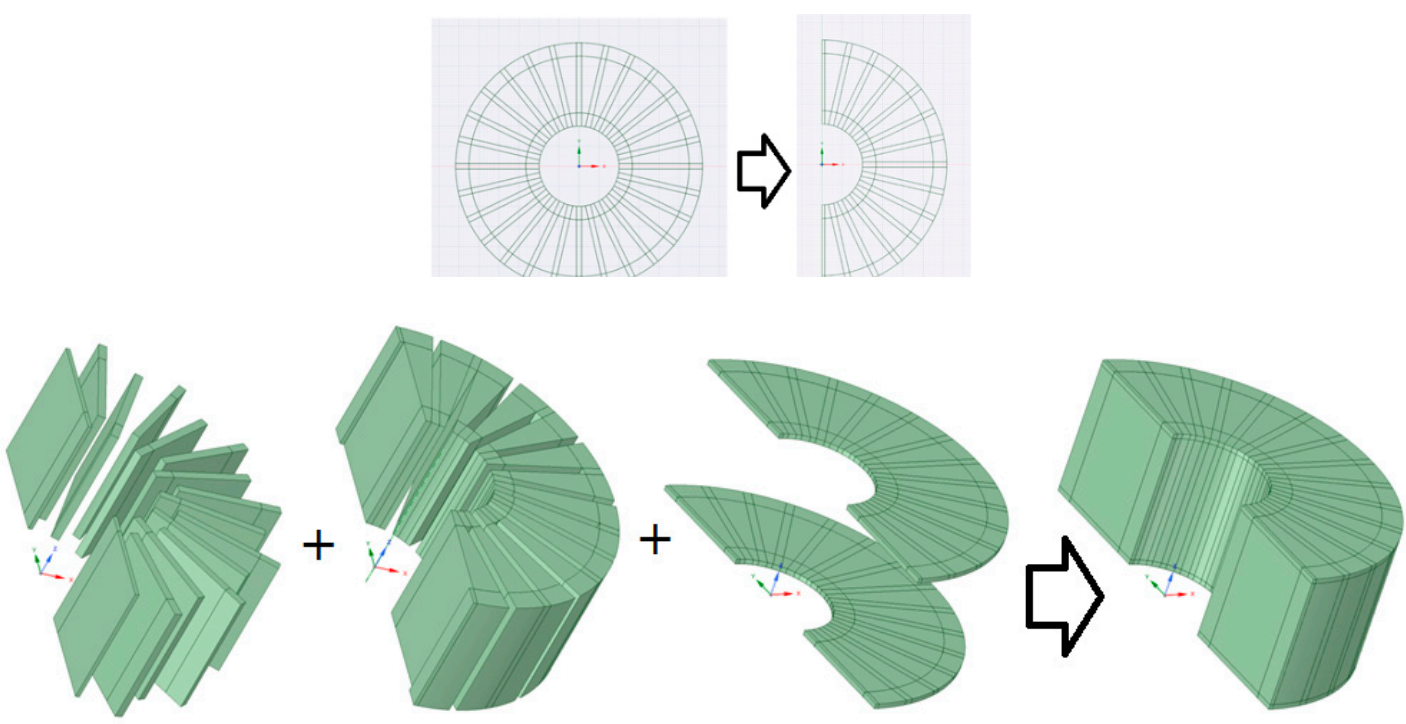

Figure 4. Suggested battery thermal management system.

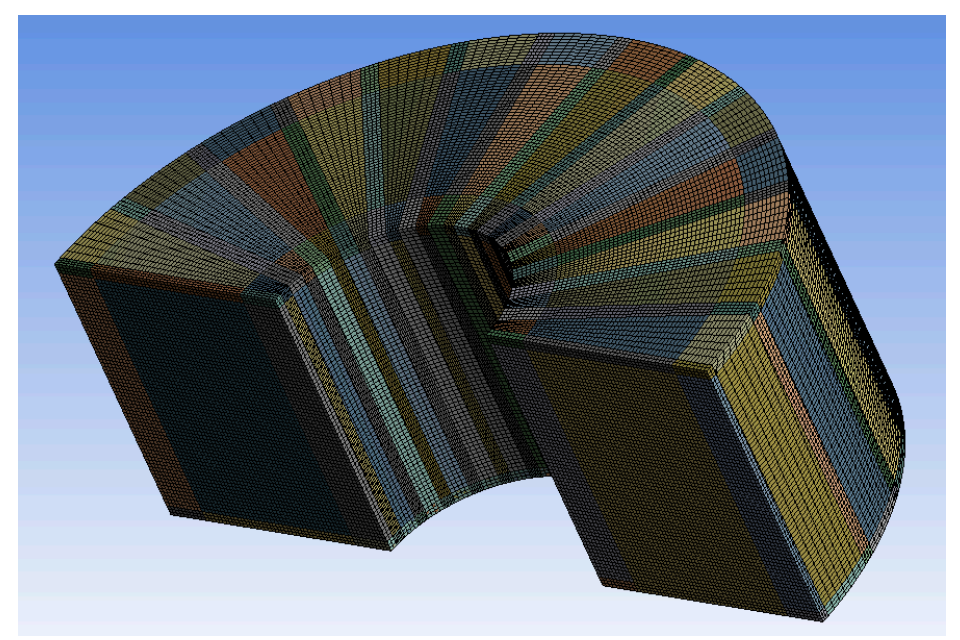

Figure 5. Schematic graph of the meshed.

Specific heat capacity, density, and thermal conductivity of the carbon fiber were considered $500 \mathrm{~J} / \mathrm{kg} \mathrm{K}, 2000 \mathrm{~kg} / \mathrm{m}^{3}, 50 \mathrm{~W} / \mathrm{m} \mathrm{K}$ respectively. Latent heat of fusion, Thermal conductivity of solid phase, Density (solid phase), Density (liquid phase), Melting point temperature $242 \mathrm{~kJ} / \mathrm{kg}, 0.21 \mathrm{~W} / \mathrm{m} \mathrm{K}$, $912 \mathrm{~kg} / \mathrm{m}^{3}, 768 \mathrm{~kg} / \mathrm{m}^{3}, 46^{\circ} \mathrm{C}$, respectively [33].

Convection through thermal air management is not a suitable method for thermal management purposes. Consequently, other thermal management systems could be employed to control the lithium-ion battery temperature. The experiment outcomes for natural convection show that during $9 \mathrm{C}$, the battery temperatures increase to about $53^{\circ} \mathrm{C}$ from $30^{\circ} \mathrm{C}$, which is an increase of $23^{\circ} \mathrm{C}$, approximately.

Thermal management of lithium-ion batteries is essential because these batteries would have a substantial rise in the temperature and heat loss gradient throughout rapid discharging because of the irreversible and reversible heat. This could be obtained without extreme complicatedness by employing a passive cooling system that contains phase change materials as coolant.

The effect of adding carbon fiber phase change material composite on the differences of battery temperature along the radial and height is shown in Figure 6. The temperature profiles of phase change material composites with carbon fibers for 3 C, 5 C, 7 C, and $9 \mathrm{C}$ are illustrated in Figure 6. It could be seen from the figure that the battery temperature increases up to $33.1,38.4,44.6$, and $49.7^{\circ} \mathrm{C}$ during $3 \mathrm{C}, 5 \mathrm{C}, 7 \mathrm{C}$, and $9 \mathrm{C}$, respectively, for phase change material composites with carbon fibers. 
It could be concluded that the phase change material would behave as a heat sink for the produced heat throughout the battery charge and discharge. It could be seen that the attendance of phase change material carbon fibers influences the temperature distribution within the thermal management system. The effect of adding carbon fiber phase change material composites on variations of the mass fraction is illustrated in Figure 7. The greatest mass fraction appears during $9 \mathrm{C}$. It could be seen from the figures that the temperature variation between the composite and battery is decreased toward a bigger radial. The simulation approach, which is indicated in this research, could cooperate with the advancement of a battery thermal management system that facilitates lithium-ion batteries' temperature development as an interdependent of time to be more exactly determined. Moreover, it could contribute to forecast the evolution of the electrical, thermal, and chemical processes. These results will assist in designing an appropriate battery thermal management system for the pack. In addition, this methodology can be advantageous for an accurate temperature forecast, which is essential to refrain from temperature nonhomogeneity in the battery cell. To achieve a reliable temperature profile and heat generation, it is possible to combine the heat loss into computational fluid dynamics and use simulation methods, anticipating the battery thermal behavior.

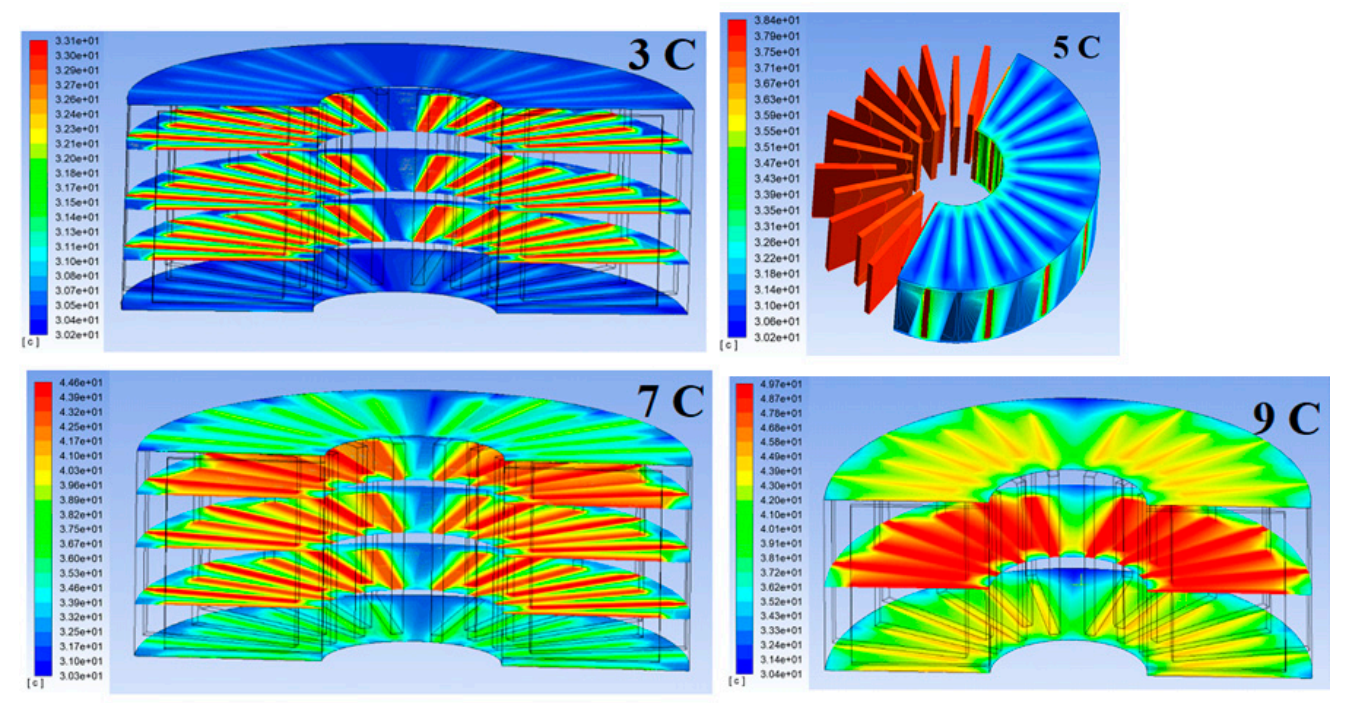

Figure 6. Simulation result of temperature contours.

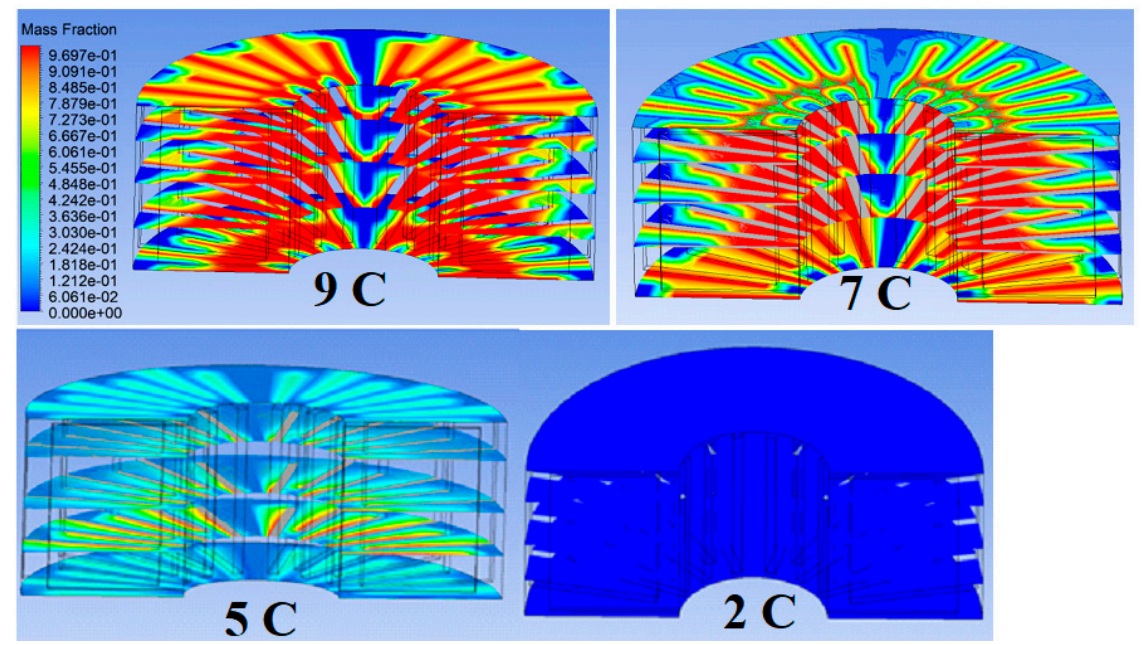

Figure 7. Simulation result of the mass fraction. 


\section{Conclusions}

The goal of this investigation was to numerically study the lithium-ion battery pack thermal management by using phase change material. The influence of adding carbon fiber phase change material on thermal performance was investigated. The principal objective of employing the phase change material in designing thermal management systems for lithium-ion batteries is to minimize the extreme temperature increase in the lithium-ion batteries and construct temperature homogeneity within the battery pack. Phase change materials are considered advantageous in different heat transfer applications because of their sensible and latent heat capabilities. The main objective of this investigation was to simulate the cooling performance of phase change material composites with carbon fibers for thermal management of lithium-ion batteries. The outcomes demonstrated that the attendance of carbon fiber phase change material improves the cooling system's efficacious thermal performance and, consequently, affects temperature distribution within the lithium-ion battery. The greatest temperature at the end of $9 \mathrm{C}, 7 \mathrm{C}, 5 \mathrm{C}$, and $3 \mathrm{C}$ charges and discharges were approximately 49.7, 44.6, 38.4, and $33.1^{\circ} \mathrm{C}$, respectively. The current thermal simulation will be complementarily optimized in a future investigation. The lithium-ion battery's experimental temperatures profile while it is discharged and charged with dissimilar current rates will be used as the input data for the simulation. The main objective of future study is to identify the optimal quantity of the phase change material required per battery cell and to improve the sketch of the battery thermal management system. Consequently, future research will focus on creating a more efficient, simpler, and less costly thermal management system for batteries.

Author Contributions: S.S.M. proposed the idea of the paper; S.S.M. wrote the paper; E.S. provided suggestions on the content and structure of the paper; S.K.K. and E.S. has been reviewing the draft manuscripts. All authors have read and agreed to the published version of the manuscript.

Funding: This research received no external funding.

Conflicts of Interest: The authors declare no conflict of interest.

\section{References}

1. Ritchie, A.; Howard, W. Recent developments and likely advances in lithium-ion batteries. J. Power Sources 2006, 162, 809-812. [CrossRef]

2. Malik, M.; Dincer, I.; Rosen, M.A. Review on the use of phase change materials in battery thermal management for electric and hybrid electric vehicles. Int. J. Energy Res. 2016, 40, 1011-1031. [CrossRef]

3. Hannan, M.; Hoque, M.M.; Mohamed, A.; Ayob, A. Review of energy storage systems for electric vehicle applications: Issues and challenges. Renew. Sustain. Energy Rev. 2017, 69, 771-789. [CrossRef]

4. Chauque, S.; Oliva, F.; Visintin, A.; Barraco, D.; Leiva, E.; Cámara, O. Lithium titanate as anode material for lithium ion batteries: Synthesis, post-treatment and its electrochemical response. J. Electroanal. Chem. 2017, 799, 142-155. [CrossRef]

5. Farmann, A.; Waag, W.; Sauer, D.U. Application-specific electrical characterization of high power batteries with lithium titanate anodes for electric vehicles. Energy 2016, 112, 294-306. [CrossRef]

6. Andre, D.; Meiler, M.; Steiner, K.; Wimmer, C.; Soczka-Guth, T.; Sauer, D.U. Characterization of high-power lithium-ion batteries by electrochemical impedance spectroscopy. I. Experimental investigation. J. Power Sources 2011, 196, 5334-5341. [CrossRef]

7. Zhang, L.; Peng, H.; Ning, Z.; Mu, Z.; Sun, C.Y. Comparative research on RC equivalent circuit models for lithium-ion batteries of electric vehicles. Appl. Sci. 2017, 7, 1002. [CrossRef]

8. Wang, Q.; Ping, P.; Zhao, X.; Chu, G.; Sun, J.; Chen, C. Thermal runaway caused fire and explosion of lithium ion battery. J. Power Sources 2012, 208, 210-224. [CrossRef]

9. Lu, L.; Han, X.; Li, J.; Hua, J.; Ouyang, M. A review on the key issues for lithium-ion battery management in electric vehicles. J. Power Sources 2013, 226, 272-288. [CrossRef] 
10. Lu, T.-Y.; Chiang, C.-C.; Wu, S.-H.; Chen, K.-C.; Lin, S.-J.; Wen, C.-Y.; Shu, C.-M. Thermal hazard evaluations of 18650 lithium-ion batteries by an adiabatic calorimeter. J. Therm. Anal. Calorim. 2013, 114, 1083-1088. [CrossRef]

11. Bhide, S.; Shim, T. Novel Predictive Electric Li-Ion Battery Model Incorporating Thermal and Rate Factor Effects. IEEE Trans. Veh. Technol. 2011, 60, 819-829. [CrossRef]

12. Zhao, X.W.; Zhang, G.Y.; Yang, L.; Qiang, J.X.; Chen, Z.Q. A new charging mode of batteries with LiFePO4/C composites under low. J. Therm. Anal. Calorim. 2010, 104, 561-567. [CrossRef]

13. Chen, Y.; Evans, J.W. Thermal analysis of lithium polymer electrolyte batteries by a two dimensional model—thermal behaviour and design optimization. Electrochim. Acta 1994, 39, 517-526. [CrossRef]

14. Al Hallaj, S.; Prakash, J.; Selman, J.R. Characterization of commercial Li-ion batteries using electrochemical calorimetric measurements. J. Power Sources 2000, 87, 186-194. [CrossRef]

15. Maleki, H.; Shamsuri, A.K. Thermal analysis and modeling of a notebook computer battery. J. Power Sources 2003, 115, 131-136. [CrossRef]

16. Pesaran, A.; Vlahinos, A.; Burch, S. Thermal Performance of EV and HEV Battery Modules and Pack; National Renewable Energy Laboratory: Golden, CO, USA, 1997.

17. Onda, K.; Ohshima, T.; Nakayama, M.; Fukuda, K.; Araki, T. Thermal be-havior of small lithium-ion battery during rapid charge and discharge cycles. J. Power Sources 2005, 158, 535-542. [CrossRef]

18. Choi, Y.S.; Kang, D.M. Prediction of thermal behaviors of an air-cooled lithium-ion battery system for hybrid electric vehicles. J. Power Sources 2014, 270, 273-280. [CrossRef]

19. Wang, T.; Tseng, K.; Zhao, J.; Wei, Z. Thermal investigation of lithium-ion battery module with different cell arrangement structures and forced air-cooling strategies. Appl. Energy 2014, 134, 229-238. [CrossRef]

20. Wang, T.; Tseng, K.; Zhao, J. Development of efficient air-cooling strategies for lithium-ion battery module based on empirical heat source model. Appl. Therm. Eng. 2015, 90, 521-529.

21. Yang, N.; Zhang, X.; Li, G.; Hua, D. Assessment of the forced air-cooling performance for cylindrical lithium-ion battery packs: A comparative analysis between aligned and staggered cell arrangements. Appl. Therm. Eng. 2015, 80, 55-65. [CrossRef]

22. $\mathrm{Xu}, \mathrm{X}$.; He, R. Research on the heat dissipation performance of battery pack based on forced air cooling. J. Power Sources 2013, 240, 33-41. [CrossRef]

23. Zhao, J.; Rao, Z.; Huo, Y.; Liu, X.; Li, Y. Thermal management of cylindrical power battery module for extending the life of new energy electric vehicles. Appl. Therm. Eng. 2015, 85, 33-43. [CrossRef]

24. Mohammadian, S.K.; Rassoulinejad-Mousavi, S.M.; Zhang, Y. Thermal management improvement of an air-cooled high-power lithium-ion battery by embedding metal foam. J. Power Sources 2015, 296, 305-313. [CrossRef]

25. Azizi, Y.; Sadrameli, S. Thermal management of a LiFePO4 battery pack at high temperature environment using a composite of phase change materials and aluminum wire mesh plates. Energy Convers. Manag. 2016, 128, 294-302. [CrossRef]

26. Karimi, G.; Azizi, M.; Babapoor, A. Experimental study of a cylindrical lithium ion battery thermal management using phase change material composites. J. Energy Storage 2016, 8, 168-174. [CrossRef]

27. Zhao, Y.; Zou, B.; Li, C.; Ding, Y. Active cooling based battery thermal management using composite phase change materials. Energy Procedia 2019, 158, 4933-4940. [CrossRef]

28. Ling, Z.; Chen, J.; Fang, X.; Zhang, Z.; Xu, T.; Gao, X.; Wang, S. Experimental and numerical investigation of the application of phase change materials in a simulative power batteries thermal management system. Appl. Energy 2014, 121, 104-113. [CrossRef]

29. Yang, H.; Zhang, H.; Sui, Y.; Yang, C. Numerical Analysis and Experimental Visualization of Phase Change Material Melting Process for Thermal Management of Cylindrical Power Battery. Appl. Therm. Eng. 2018, 128, 489-499. [CrossRef]

30. Madani, S.S.; Schaltz, E.; Kær, S.K. Heat loss measurement of lithium titanate oxide batteries under fast charging conditions by employing isothermal calorimeter. Batteries 2018, 4, 59. [CrossRef]

31. Madani, S.S.; Schaltz, E.; Kær, S.K. Study of temperature impacts on a lithium-ion battery thermal behaviour by employing isothermal calorimeter. ECS Trans. 2018, 87, 295-305. [CrossRef] 
32. Madani, S.S.; Schaltz, E.; Kær, S.K. Simulation of thermal behaviour of a lithium titanate oxide battery. Energies 2019, 12, 679. [CrossRef]

33. Samimi, F.; Babapoor, A.; Azizi, M.; Karimi, G. Thermal management analysis of a Li-ion battery cell using phase change material loaded with carbon fibers. Energy 2016, 96, 355-371. [CrossRef]

Publisher's Note: MDPI stays neutral with regard to jurisdictional claims in published maps and institutional affiliations.

(C) 2020 by the authors. Licensee MDPI, Basel, Switzerland. This article is an open access article distributed under the terms and conditions of the Creative Commons Attribution (CC BY) license (http://creativecommons.org/licenses/by/4.0/). 